\title{
HUBUNGAN REINFORCEMENT TERHADAP DISIPLIN ANAK USIA DINI DI PAUD PEMBINA 1 KOTA BENGKULU \\ (Studi Deskriptif Kuantitatif Di PAUD Pembina 1 Kota Bengkulu)
}

\author{
Viona Calista S \\ vionacalista13@gmail.com \\ Nina Kurniah \\ ninakurniah@unib.ac.id \\ Mona Ardina \\ mona.ardina@gmail.com
}

\begin{abstract}
This research aimed at investigating the relationship between reinforcement towards the early preschoolers' discipline at Pembina 1 Preschool Bengkulu City. The method used was quantitative descriptive with Correlational type. The subjects of this research were the B3 class consisting of 1 teacher and 14 students at Pembina 1 Preschool Bengkulu City. The data collection technique was conducted through observation in the form of checklist. The data were analyzed by using Product-Moment Correlation. Based on the data processing result, it indicated that there was a significant relation between the reinforcement and the preschoolers' discipline at the Pembina 1 Preschool Bengkulu City which the Ha was approved while the Ho was rejected. Therefore, this research suggests that teachers have to maintain and improve the implementation of reinforcement in instilling the discipline to the Preschoolers
\end{abstract}

Keywords: Reinforcement; Preschooler Discipline

\section{PENDAHULUAN}

Menurut Undang-undang No. 20 Tahun 2003 Pendidikan nasional bertujuan untuk mengembangkan potensi peserta didik agar menjadi manusia yang beriman dan bertakwa kepada Tuhan Yang Maha Esa, berakhlak mulia, sehat, berilmu, cakap, kreatif, mandiri, dan menjadi warga negara yang demokratis serta bertanggung jawab.

Menurut Slameto (2010:54) ada dua faktor yang mempengaruhi belajar anak, yaitu faktor intern dan ekstern. Faktor intern yaitu faktor yang ada dalam diri individu, meliputi jasmani, rohani dan kelelahan. Faktor ekstern yaitu faktor dari luar individu yang meliputi lingkungan keluarga, sekolah dan masyarakat. Salah satu faktor ekstern yang menentukan keberhasilan kegiatan belajar anak di sekolah adalah faktor guru dan cara mengajarnya. Guru sangat berperan terhadap pembentukan perkembangan anak.

Seorang guru harus menguasai keterampilan mengajar. Hal ini sesuai dengan pendapat Uno (2010:168) yang mengatakan "keterampilan mengajar guru merupakan salah satu jenis keterampilan yang harus dikuasai guru. Dengan demikian, dalam keterampilan mengajar, guru dapat 
mengelola proses pembelajaran dengan baik yang berimplikasi pada peningkatan kualitas lulusan sekolah"

Menurut Winkel (dalam Uno 2010:168) mengemukakan keterampilan dasar yang harus dikuasai oleh guru yaitu: keterampilan menjelaskan, memberikan penguatan, bertanya, serta membuka dan menutup pelajaran. Ditambahkan oleh Menurut Usman (2013:74) dan Suwarna (2006:66-92) keterampilan dasar mengajar yang harus dikuasai oleh guru yaitu: mengadakan variasi, membimbing diskusi kelompok kecil, mengelola kelas, dan mengajar perseorangan dan keterampilan menggunakan media pembelajaran. Berdasarkan pendapat para ahli diatas dalam penelitian ini difokuskan pada keterampilan guru dalam memberikan penguatan.

Penguatan (reinforcement) menurut Usman (2013:80) adalah segala bentuk respon, apakah bersifat verbal maupun nonverbal, yang merupakan bagian dari modifikasi tingkah laku guru terhadap tingkah laku anak, yang bertujuan untuk memberikan informasi atau umpan balik (feedback) bagi si penerima (anak) atas perbuatannya sebagai suatu tindak dorongan ataupun koreksi.

Gichara (2012:76) menyatakan bahwa disiplin berasal dari kata disciples artinya murid. Itu berarti, ketika guru menerapkan disiplin, guru tidak menyiksa seorang anak melainkan sedang membentuknya menjadi murid yang taat dan tertib. Disiplin dapat mencakup pengajaran, bimbingan, atau dorongan yang dilakukan orangtua kepada anaknya. Shochib (2000:3) Anak yang berdisiplin memiliki keteraturan diri berdasarkan nilai agama, nilai budaya, aturan-aturan pergaulan, pandangan hidup, dan sikap hidup yang bermakna bagi dirinya sendiri, masyarakat, bangsa dan negara.

Dalam disiplin anak pada kenyataannya masih ditemukan anak-anak yang belum disiplin seperti halnya anak- anak di PAUD negeri Pembina 1 kota Bengkulu kelas B3 dimana masih terdapat anak yang tidak disiplin, seperti tidak memakai seragam sekolah, tidak memakai atribut lengkap, mengobrol saat pelaksanaan sholat berlangsung, tidak mengikuti sholat berjamaah, datang terlambat ke sekolah, mengganggu teman saat sholat, asyik mengobrol dan bercanda dengan teman, tidak ikut berdoa, berteriak, tidak mau membereskan peralatan seperti lembar kerja, buku, pensil, dan pewarna ketika selesai pembelajaran atau selesai digunakan. Namun anak di kelas B3 tersebut juga ada beberapa orang yang sudah disiplinnya, seperti datang tidak terlambat, meletakkan sepatu pada rak sepatu dan menggantung tas pada tempatnya.

Berdasarkan permasalahan tersebut peneliti akan melihat reinforcement terhadap disiplin anak. Judul dalam penelitian ini adalah "hubungan reinforcement terhadap disiplin anak usia dini di PAUD Pembina 1 Kota Bengkulu"

Berdasarkan latar belakang dapat dirumuskan masalah menjadi: "Apakah terdapat hubungan reinforcement terhadap disiplin anak B3 di PAUD Negeri Pembina 1 Kota Bengkulu?"

reinforcement adalah penguatan yang positif. Merupakan sebuah motivasi untuk anak dan pemberiannya harus tepat. Dengan penguatan yang tepat akan memupuk suasana yang menyenangkan dan mempertinggi gairah belajar serta sekaligus akan membangkitkan harga diri. Reinforcement (penguatan) adalah sebuah penguatan yang positif dan negatif. Sedangkan pengertian disiplin menurut Ruswandi (2013:184) disiplin dapat diartikan ketaatan pada peraturan dan tata tertib. Disiplin merupakan sikap dan perilaku taat dan patuh terhadap nilai-nilai yang dipercaya atau peratuan yang berlaku. 
Komponen keterampilan memberi penguatan menurut Hasibuan dan Moedjiono (2006: 59) yaitu sebagai berikut:

a) Penguatan verbal. Penguatan verbal dapat berupa kata-kata atau kalimat yang diucapkan guru. Contoh, "baik, bagus, tepat, saya sangat menghargai pendapatmu, pikiranmu sangat cerdas, dan lain-lain. b) Penguatan gestural. Penguatan yang diberikan dalam bentuk mimik wajah, gerakan wajah atau anggota badan yang dapat memberikan kesan kepada anak. c) Penguatan dengan cara mendekati. Penguatan ini dikerjakan dengan cara mendekati anak untuk menyatakan perhatian guru terhadap perkerjaaan, tingkah laku atau penampilan anak. d) Penguatan dengan sentuhan. Guru dapat menyatakan penghargaan kepada anak dengan menepuk pundak anak, menjabat tangan anak, atau mengangkat tangan anak. e) Penguatan dengan memberikan penguatan yang menyenangkan. Penguatan ini berupa meminta anak untuk membantu temannya bila anak terlebih dahulu selesai dalam mengerjakan pekerjaannya. f) Penguatan berupa tanda atau benda. Penguatan bentuk ini merupakan usaha guru dalam menggunakan bermacammacam simbol penguatan untuk menunjang tingkah laku anak yang positif.

Asmani (dalam Arlin, 2015:36) menyatakan bahwa indikator disiplin yaitu sebagai berikut: 1) Disiplin waktu, 2) Disiplin dalam beribadah, 3) Disiplin menegakkan aturan dan 4) Disiplin sikap.

\section{METODE PENELITIAN}

Metode yang digunakan dalam penelitian ini adalah korelasional yang bertujuan untuk mengetahui ada atau tidak adanya hubungan reinforcement dengan disiplin anak usia dini. Populasi dalam penelitian ini adalah seluruh anak kelompok B di PAUD Negeri Pembina 1 Kota Bengkulu tahun ajaran 2016/2017 yang berjumlah 86 orang. Anak kelompok $B$ terdiri dari 5 kelas yaitu B1, B2, B3, B4 dan B5. Sampel dalam penelitian ini menggunakan teknik stratified purposive sampling yaitu kelompok B3 yang berjumlah 14 orang anak. Teknik Pengumpulan data yang digunakan dalam penelitian ini adalah observasi dengan bentuk ceklis.

\section{HASIL DAN PEMBAHASAN}

Berdasarkan perhitungan rata-rata dari skor reinforcement (penguatan) adalah 26 dengan jumlah item pertanyaan 30, maka diperoleh perhitungan persentase sebesar $86 \% \mathrm{Hal}$ ini menunjukkan bahwa reinforcement (penguatan) yang diterapkan oleh guru di PAUD Negeri Pembina 1 Kota Bengkulu dalam klasifikasi yang sangat baik. Artinya guru telah menerapkan reinforcement (penguatan) dengan pemberian penguatan verbal, penguatan gestural, penguatan dengan cara mendekati, penguatan dengan sentuhan, penguatan dengan memberikan kegiatan yang menyenangkan dan penguatan berupa tanda atau benda.

Berdasarkan perhitungan jumlah ratarata dari skor disiplin anak adalah 23 , maka di peroleh perhitungan persentase disiplin anak sebesar $78 \%$. Hal ini menunjukkan bahwa disiplin anak di PAUD Negeri Pembina 1 Kota Bengkulu juga dalam klasifikasi baik. Artinya disiplin anak usia dini telah terbentuk. Anak sudah disiplin waktu, disiplin menegakkan aturan , disiplin sikap dan disiplin dalam beribadah.

Berdasarkan data tersebut, maka perhitungan antara reinforcement (penguatan) (Variabel $X$ ) dan disiplin anak (Variabel $Y$ ) dengan menggunakan rumus product moment diperoleh koefisien korelasi product moment $\mathrm{r}_{\text {hitung }}$ sebesar 1 . pada taraf $5 \%(0,05)$. Dengan demikian terbukti bahwa $r_{\text {hitung }}(1,00)>r_{\text {tabel }}(0,576)$, sehingga Ha diterima dan Ho ditolak. Hal ini menunjukan bahwa terdapat hubungan yang signifikan antara reinforcement (penguatan) dengan disiplin anak dimana terletak pada interval 0,80-1,000 dengan tingkat hubungan yang sangat kuat, jadi 
dapat disimpulkan bahwa hubungan reinforcement (penguatan) dengan disiplin anak usia dini memiliki hubungan yang sangat kuat.

Berdasarkan hasil penelitian tersebut, dapat dilihat bahwa rata-rata reinforcement (penguatan) yang diterapkan oleh guru di PAUD Negeri Pembina 1 Kota Bengkulu dalam klasifikasi yang sangat baik. Hal ini menunjukkan peran guru dalam memberikan penerapan reinforcement (penguatan) sangat penting terhadap disiplin anak. Disiplin anak tidak lepas dari penerapan reinforcement (penguatan), dimana penerapan reinforcement (penguatan) dapat membentuk anak yang disiplin. Hasibuan dan Moedjiono (2006:58), mengatakan "memberikan penguatan diartikan tingkah laku guru dalam merespon secara positif suatu tingkah laku tertentu anak yang memungkinkan tingkah laku tersebut timbul kembali". Oleh karena itu, reinforcement (penguatan) guru seharusnya memiliki sifat-sifat yang dapat membawa anak ke arah yang baik.

Disiplin anak di PAUD Negeri Pembina 1 Kota Bengkulu juga dalam klasifikasi baik. Sejalan dengan pendapat Sujiono (2005:31) adalah memberitahu dan mengarahkan anak tentang mana perilaku yang baik dan benar dan mana prilaku tidak baik dan tidak benar. Selain itu, untuk mendorong anakagar berperilaku sesuai dengan norma yang berlaku di masyarakat ataupun dilingkungan.

Berdasarkan pengujian hipotesis membuktikan bahwa terdapat hubungan yang signifikan antara reinforcement dengan disiplin anak usia dini. Artinya penerapan reinforcement yang diberikan semakin baik maka semakin baik pula disiplin anak. Hal tersebut telah terbukti pada penelitian di PAUD Negeri Pembina 1 Kota Bengkulu yang menunjukkan penerapan reinforcement yang dilakukan guru berdampak pada disiplin anak.
Hasil penelitian ini adalah terdapat hubungan yang signifikan antara hubungan reinforcement dengan disiplin anak usia dini di PAUD Pembina 1 Kota Bengkulu pada kategori sangat baik.

\section{PENUTUP}

\section{Simpulan}

Berdasarkan hasil penelitian dan pengolahan data yang dilakukan, maka dapat disimpulkan bahwa terdapat hubungan yang signifikan antara reinforcement (penguatan) dengan disiplin anak di PAUD Negeri Pembina 1 Kota Bengkulu.

Saran

Berdasarkan kesimpulan di atas, maka penulis mengajukan saran-saran sebagai berikut:

1) Bagi guru hendaknya guru mempertahankan reinforcement (penguatan) yang diberkan pada anak agar tetap konsisnten dan lebih seperti penguatan yang menciptakan suasana yang hangat, antusias, bermakna, dan motivasi yang positif agar anak tumbuh menjadi pribadi yang disiplin dan patuh pada aturan tanpa paksaan dan sesuai dengan tahapan usianya.

2) Untuk penelitian selanjutnya dapat melakukan penelitian reinforcement (penguatan) tetapi dikaitkan dengan menggunakan pembelajaran sentra, dalam kegiatan pembelajaran, mengembangkan keterampilan untuk anak didik yang lain.

\section{DAFTAR PUSTAKA}

Arlin, Meila. Skripsi (2015). Hubungan reward dengan disiplin anak TK kelompok b disekolah se-gugus ii kecamatan sanden, Bantul. Yogjakarta: Jurusan Pendidikan Prasekolah Dan Sekolah Dasar. Universitas Negeri Yogyakarta.

Gichara, Jenny. (2012). Kelas Sehat Prestasi Hebat. Jakarta : PT. Gramedia. 
Hasibuan dan Moedjiono. (2006). Proses Belajar Mengajar. Bandung: Remaja Rosdakarya.

Ruswandi, (2013). Pisikologi Pembelajaran. Bandung : CV. Cipta Pesona Sejahtera.

Slameto. (2010). Belajar Dan Faktor-Faktor Yang Mempengaruhinya. Jakarta: Rineka Cipta.

Shochid, Moh. (2000). Pola Asuh Orangtua Dalam Membantu Anak Mengembangkan Disiplin Diri. Jakarta : Rineka Cipta.

Subagyo, Joko. (2011). Metode Penelitian dalam Teori dan Praktik. Jakarta: Rineka Cipta.

Surdiman. (2011). Interaksi dan Motivasi Belajar Mengajar. Jakarta: Rajawali Pers.

Sujiono, Yuliani Nuraini. (2005). Mencerdaskan Prilaku Anak Usia Dini. Jakarta: Elex Media Kompurido.

Uno, Hamzah B. (2010). Orientasi Baru dalam Psikologi Pembelajaran. Jakarta: Bumi Aksara.

Usman, Moh. Uzer. (2013). Menjadi Guru Profesional. Bandung: Remaja Rosdakarya. 